\title{
SNAKEBITES IN PARAÍBA, BRAZIL
}

\section{ALBUQUERQUE H. N. (1,3), FERNANDES A. (2), ALBUQUERQUE I. C. S. (3)}

(1) Department of Pharmacy and Biology, Paraíba State University, Paraíba, Brazil;

(2) Department of Nursing, Paraíba State University, Paraíba, Brazil; (3) Center for the Caatinga Reptiles Conservation, Campina Grande, Paraíba, Brazil.

\begin{abstract}
The epidemiological data on snakebites in the state of Paraíba, Brazil, is scarce. This accounts for the difficulties in helping the victims. Hence, to obtain the clinical and epidemic profile of the snakebite accidents in Paraíba, we studied the number of cases recorded in this state between January 1995 and December 2000. The data was collected from these sources: Center for Toxicological Assistance (Centro de Assistência Toxicológica - CEATOX) and State Secretariat of Health (Secretaria Estadual de Saude), João Pessoa; $3^{\text {rd }}$ Regional Health Center ( $3^{\circ}$ Núcleo Regional de Saúde - NRS) and the Division of Epidemiological Vigilance of the Municipal Secretariat of Health (Divisão de Vigilância Epidemiológica da Secretaria Municipal de Saúde - DVE/SMS), Campina Grande. The annual distribution of the snakebite incidence showed an irregularity and an increase in March, May and August; followed by a large reduction in November and December. It was also observed that snakebites occurred more frequently in the rural area, mainly among the male laborers between 10-49 years. In most cases, the bite occurred on the leg or foot. The interval between the snakebite and the medical assistance was less than six hours. The most common symptoms were pain, edema, erythema, and bleeding. The low lethality index and the high frequency of healing, without sequels, suggest that the treatment with serum neutralized the poison, indicating the efficacy of this treatment against snakebites by the specific species found in this region.
\end{abstract}

KEY WORDS: ophidic accident, Paraíba, public health care, environment.

\section{CORRESPONDENCE TO:}

H. N. ALBUQUERQUE, Rua Manoel Joaquim Ribeiro, 382, Bodocongó, 58109-170, Campina Grande, PB, Brasil, Phones: 833339233 or 8801 8130, Fax: 833333886.

Email: helderalbuquerque@bol.com.br 


\section{INTRODUCTION}

The snakes, descendants of lizards, appeared in the Lower Cretaceous about 100 to 130 million years ago. Belonging to the class Reptilia (Reptiles), order Squamata, the snakes have 15 families and approximately 2500-3000 species distributed worldwide. Snakebite is a global problem. In the tropical regions, the rate of annual incidents can vary according to the geographical divisions. In the western hemisphere, most of the victims were attacked by snakes from the Viperidae family, sub-family Crotalidae, which in South America is represented by the Bothrops, Crotalus, and Lachesis (4, $10,11,14)$ species. Apart from these, other species such as: jararacas, rattlesnakes, bushmaster snakes and coral snakes are part of the Brazilian venomous ophidian fauna. However, there are records of severe accidents caused by other species as well. For example, the species Clelia sp and Philodryas (4, 10), which, normally, are not considered to be poisonous.

In the Northeast of Brazil, snakebite studies are scarce, what further complicates the assistance to the victims. According to the Epidemiological Information Bulletins of the Single Health System (Sistema Único de Saúde - SUS) (5), between 1997 and 1998, in the state of Paraíba, only 25 notifications of ophidian accidents were sent to the Health Ministry. This number does not match with the actual number of cases in this state. According to the data obtained $(1,3)$, only in the micro-regions of Cariri and Borborema, Paraíba, between 1997-1998, 263 cases of ophidian accidents were recorded. This data, provided by the Health Agencies of Paraíba, underestimate the real situation of the snakebite in all the micro-regions of the state.

As the study on snakebites is still scarce in our state, for the present work, it was of fundamental importance to present a clinical and epidemic profile of the snakebite accidents in Paraíba. Only with the exact information about these accidents and with the aim of identifying the signals and the symptoms, as well as the animal aggression (although late), can one contribute to improving the quality of the assistance to the victims so that they have a shorter stay in the hospitals. Only with the systematic analysis of the data is it possible to offer an adequate diagnosis and treatment for snakebite in Paraìba. 


\section{MATERIALS AND METHODS}

\section{Source of data}

The clinical and epidemiological data analyzed in this work included 1988 file cards obtained from two main sources: First, from the archives of the Paraíba State, recorded between January 1995 and December 2000 by the Toxicological Assistance (Assistência Toxicológica - CEATOX) and also by the State Secretariat of Health (Secretaria Estadual de Saude), João Pessoa. Second, from the archives of the $3^{\text {rd }}$ Regional Health Center ( $3^{\circ}$ Núcleo Regional de Saúde - NRS), recorded by the Division of Epidemiological Vigilance of the Municipal Secretariat of Health (Divisão de Vigilância Epidemiológica da Secretaria Municipal de Saúde DVE/SMS), Campina Grande.

\section{Epidemiological data}

The data about the victims provided information about their age, sex, occupation, rural or urban setting, time of the accident, anatomical area bitten, the snake species, and the seasonal nature of the accidents. The identification of the snakes species was based on the information provided by the victim or his/her companion or on the observation of the signs and clinical symptoms observed by the health officials.

\section{Clinical data}

The clinical symptoms recorded were swelling, edema, erythema, ecchymosis, phlyctena, local and systemic bleeding, nausea, vomit, dizziness, anury, hyperthermia, palpebral ptosis, diplopia, myalgia, and oliguria.

\section{Method of approach}

The method utilized for the analysis was hypothetic-deductive.

\section{Analytical procedure}

We analyzed the records and files of the snakebite victims. The results are presented by descriptive statistics, using percentage, average, tables, and graphs, which can well represent the obtained data. 


\section{RESULTS}

The snakebite incidents occurred in an irregular manner during each year, presenting a high average in March and August (62.4\%) and an evident reduction between September and February (Figure 1).

The seasonal nature of the snakebite is influenced by the rainfall index. Probably, it also depends on the morpho-climatic conditions of the state, which is characterized by not well-defined climatic seasons. The average annual temperature ranges between $30^{\circ} \mathrm{C}$ and $20^{\circ} \mathrm{C}$. The tropical hot, humid, semi-humid and semi-dry climate, where the total annual rainfall is $800-1400 \mathrm{~mm}$, contributes to the snakes hunting activities throughout the year.

The predominant age range of the victims was between 30-39 years (20.9\%). However, the age ranges of 10-19 (17.5\%) and 20-29 (19.8\%) also had a considerable percentage (Figure 2).

The sex ratio seems to follow the national tendencies as confirmed by other studies $(2,3,4,7,12)$ with males being more commonly affected than females $(73.2 \%$ of the males were affected by snakebites). For obvious reasons, bite incidences are maximal in the lower limbs (70.2\%), whereas attacks on upper body parts had a smaller percentage (16.6\%) - this fact was not in the official records. The disparity in the epidemiological data reflects variations in the health reporting accuracy since the official records show that fifty percent of the snakebite victims came from the rural area. However, this information was not found in $24 \%$ of the official health records and other reports.

As also observed by other researchers (4), half of the snakebite incidents occurred in the rural area (50\%), while the urban area presented $25.6 \%$ of incidences. It is important to state that, in about $24 \%$ of the health official records, this information was not recorded. This high percentage was also missing in the studies published in other northeastern states of Brazil.

Sixty-one percent of the health official records show that the time elapsed between the snakebite and the assistance was normally less than 6 hours. In $0.9 \%$ of the victims, medical assistance availability was after six hours and this delay can be seen as a possible cause for two amputation cases and five deaths caused by the Bothrops species. However, in $30 \%$ of the official records none of these facts were recorded. Amongst the aggressor snake species, the percentage shows: Bothrops 
(46.3\%), Crotalus (10.1\%), Micrurus (1.7\%). Apart from these, $12.7 \%$ non-poisonous snakes were recorded. In $29.2 \%$ cases, the snake species was not identified.

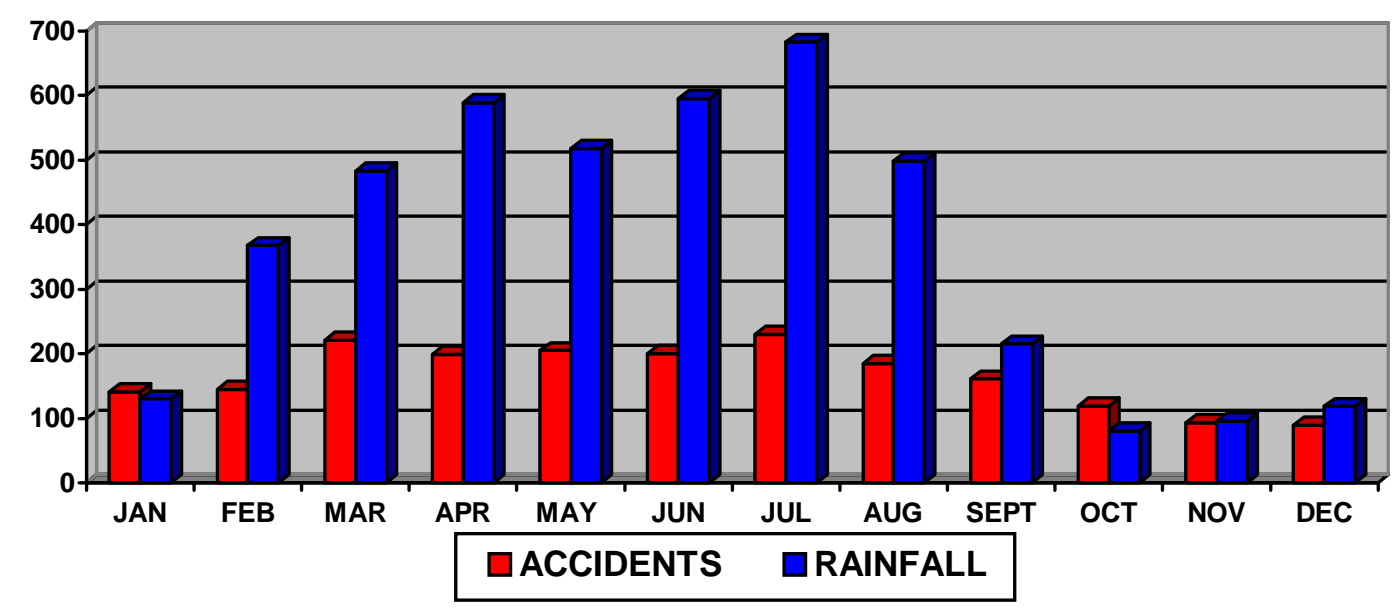

Figure 1. Seasonal nature of the ophidian accidents and monthly rainfall index in Paraíba; period: 1995-2000.

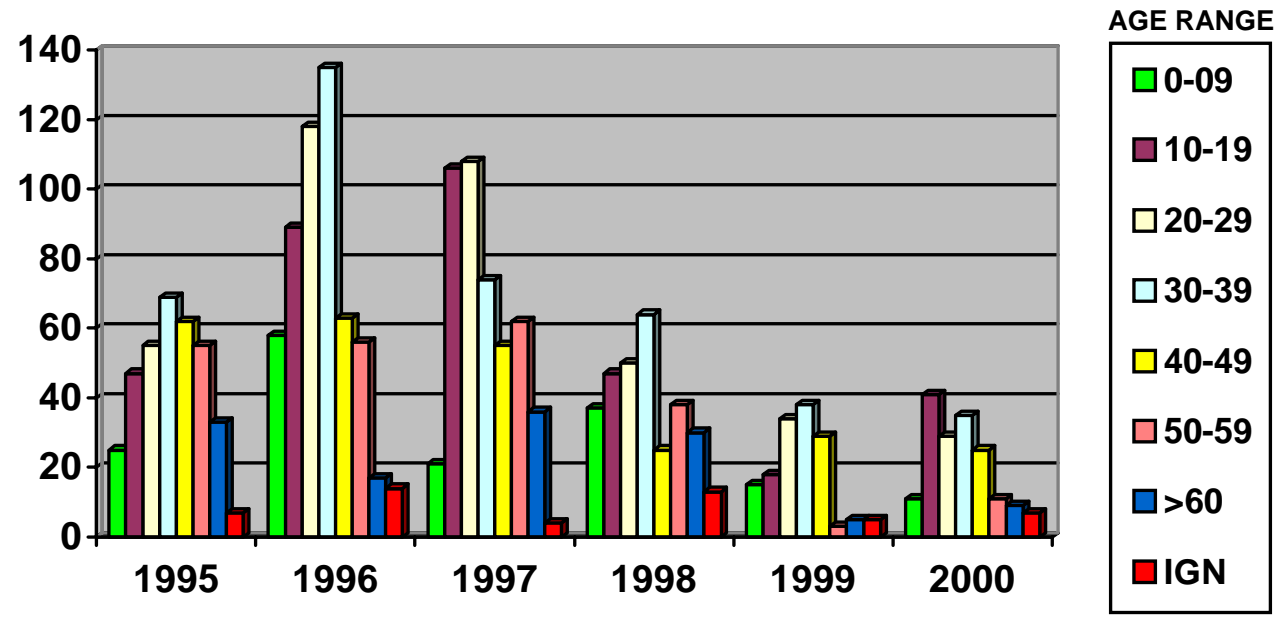

Figure 2. Distribution of the snakebite accidents according to the victims' age during the period of $1995-2000$.

\section{DISCUSSION}

The data analysis showed that the indices presented by the State official records in the years of 1997 and 1998 are in contradiction to the data published by the National Health Sectors for the state of Paraíba. According to other studies $(5,9)$, in the same period only 25 cases of snakebite were recorded in Paraíba, where, as the result of 
this study affirms, 770 cases actually occurred. These data demonstrate the omission in transferring the information from the State Health Sectors to the National Health Sectors (it is important to note that there are specific centers for these studies, such as CEATOX in the state of Paraíba, which are associated to the National Toxicological Information System - SINITOX).

The results of the present study confirm what has already been published by other authors $(1,3,6,15)$ about the occurrence of accidents in the regions of Campina Grande, Cariri, and the plains of Borborema, Paraíba, whose data do not coincide with the lowest indices shown by the National Health Sectors.

Besides the omission in transferring the data, the fact that many of the snakebite victims from Paraíba were treated and recorded as people from other states also contributes to the lack of information in the ophidian surveys in Paraiba. According to a survey made during the years of 1995-1997 (2), eight people were victims of snakebite in Paraíba but obtained medical assistance in the neighboring state of Pernambuco. This leads us to believe that, in the same way, other patients might had obtained medical assistance in other neighboring states such as Ceará and Rio Grande do Norte.

As shown in other studies $(5,11)$, in Amazônia, the seasonality contrasts the data from the Southern regions to those of the Northern regions, where the accidents peak concentrated during the hottest months of the year (from October to March).

In Paraíba, the accidents peak is proportionally inverted, since the regional population is involved with agricultural activities mainly between March and August (period of land preparation, planting, and wood chopping for campfire during feasts), what corroborates to previous studies made in this state $(1,3,5)$. This tendency confirms what has been published $(2,6,8,12,13)$ about Pernambuco, Ceará, Bahia, and Roraima States.

The studies previously performed in the state of Paraíba confirm a decrease in the number of accidents in September and more frequent occurrences in March, May and July, probably due to the explanation suggested in the pluviometric index.

High incidences of snakebites in Paraíba are more frequently observed, especially in the urban outskirts, and rural areas. Although snakebite is observed in all age groups, a great majority of the victims (71.3\%) were male between 10-49 years; this fact is in accordance with the available literature $(2,5,8)$. However, the number of 
victims below 10 years of age was also quite high (8.4\%). This might be due to the early initiation of young children in the farming activities or their accompanying their parents, facts also highlighted by the other studies $(4,5)$. This age group represents the major workforce in the field.

Apart from this, the sex factor, not recorded in the official file cards, presented interesting outcome since it showed considerable differences between male (13.2\%) and female (26.2\%) victims. This can be attributed to the fact that the participation of women in the agricultural activities in the northeastern states of Brazil is quite high. The scarce availability of domestic work and an aversion to such jobs leave very few options for women from these regions. Normally, the wives help their husbands at work, especially in the land preparation, plantation, harvesting and wood chopping, often barefoot, which leads to greater chances of snakebite.

According to the available data, in most cases the snakes mainly pounced at the foot (44.6\% of the notified records). This tendency was also verified in works from other Brazilian States: São Paulo, Amazônia, Bahia, Mato Grosso, Ceara, and Minas Gerais.

The predominance of ophidic accidents involving the hands and feet during agricultural activities determines the ophidism in Paraíba as a work accident, suggesting the use of proper shoes and gloves by the workers, which would reduce the risk of accidents from $50 \%$ to $70 \%$.

The sex factor, the specific body parts attacked, the lapse of time between the snakebite and the medical assistance are almost the same in the whole world. This shows that farming activities, improper outfits, and the difficulty in obtaining fast medical aid are the main causes of high indices of snakebite in Paraíba.

Among the snake species most responsible for the accidents in Paraíba, it was observed that only three, Bothrops, Crotalus and Micrurus, were in the official records. Another species (Lachesis) was recorded as cause of only two accidents in the state during July 1994 in the city of João Pessoa - with major incidences by Bothrops (46.3\%), followed by Crotalus (10.1\%) and Elapidae (1.7\%).

It was observed that the snakebites incidence shows a distinct seasonal pattern, closely related to rainfall and temperature. However, the majority of snakebite accidents in Paraíba occurred in the month of July. 
It was noticeable that the non-venomous snakes were in $12.7 \%$ of the official records. However, it was observed that in $29.2 \%$ cases the patients were unable to identify the species either because of ignorance or due to poor visibility in darkness. Among the Crotalus species there is a tendency of migration to the Atlantic Coastal Forests. The city of Pitimbu (in the southern coast of Paraíba) presented accidents caused by the rattlesnakes, which is quite against the biological nature of these snakes typical of regions with little humidity, hot, and stony lands.

The non-identification of the snake in an accident, as has been noted in other works too, poses certain difficulty to offer assistance to the victims. Normally, the species is identified according to the symptoms presented. However, in most cases the situation is the same as in other countries. Generally, the snake species is not identified because it was not caught and taken to the place of medical assistance or because there are no qualified people to do a taxonomical diagnosis.

The high percentage of the non-poisonous snakes (12.7\%) should be taken into consideration, since among the local cases in the state of Paraíba, where the accidents were notified as ophidic, the best results are obtained by the CEATOX of João Pessoa, where in 252 notified cases (63.5\%) the species had been identified. Still, the data are not given in totality, and the relevant clinical and epidemiological information is left open, which prevents an adequate treatment of the victims. Though the national indices recorded only the age group of 11-50 years, it was observed that, in Paraíba, another age group (0-9 years) also shows a considerable percentage of cases (8.4\%). This requires more attention from the State because each year more children enter the job market as field workers.

There seems to be a lack of training or interest among the Health professionals in this state, since the actual data on the snakes identification and the information in the record files do not match because a large number of cases are recorded without definite data. This, apart from wastage of specific serum therapy, can aggravate the victims' health. This condition reveals the need for using laboratorial diagnostic methods to secure a specific serum therapy and its controlled use, avoiding thus the loss for State and the general population. 


\section{REFERENCES}

1 ALBUQUERQUE HN., FERNANDES A., PORTO NPC. Ofidismo em João Pessoa, Paraíba, Brasil. Rev. Bras. Toxicol., 2001, 14, 178-82.

2 AQUINO EK. Epidemiologia e clínica dos acidentes ofídicos no Estado de Pernambuco. Recife: Universidade Federal de Pernambuco, 1999. 79p. [Dissertação - Mestrado]

3 BATISTA AR., ALBUQUERQUE HN., ARAÚJO JEA., BRAGA SMLFM. Acidentes botrópicos no interior paraibano. In: SIMPÓSIO DA SOCIEDADE BRASILEIRA DE TOXINOLOGIA, 5, Angra dos Reis, 1998. Abstracts... Rio de Janeiro: FIOCRUZ, 1998. p.191.

4 BRASIL. Ministério da Saúde. Fundação Nacional da Saúde. Manual de diagnóstico e tratamento de acidentes por animais peçonhentos. Brasília, 2002. 98p.

5 BRASIL. Ministério da Saúde. Sistema Nacional de Informações Tóxicofarmacológicas (SINITOX). Estatística anual de casos de intoxicação e envenenamento. Brasil: FIOCRUZ, 2001. 108p.

6 CARMO ICR. Contribuição para o estudo epidemiológico de acidentes ofídicos no Estado da Bahia no período de 1991-1992. Salvador: Universidade Federal da Bahia, 1994: 55p. [Monografia - Graduação]

7 CARVALHO Jr. AM., ALENCAR VP, COSTA FG., CABRAL B., DIAS EPF, ARRUDA Jr. ER. Acidentes ofídicos por surucucu (Lachesis muta rhombeata): relato de dois casos atendidos no HU. Rev. Cent. Ciênc. Saúde, 1994, 13, 114.

8 FEITOSA RFG., MELO IMA., MONTEIRO HSA. Epidemiologia dos acidentes por serpentes peçonhentas no Estado do Ceará - Brasil. Rev. Soc. Bras. Med. Trop., 1997, 30, 295-301.

9 INFORME EPIDEMIOLÓGICO DO SUS. Centro Nacional de Epidemiologia. Brasília: Ministério da Saúde, Fundação Nacional da Saúde, 1999. 45p. (Informe, 8)

10 JIM J., SAKATE M. Biologia das serpentes. In: BARRAVIERA B. Venenos: aspectos clínicos e terapêuticos dos acidentes por animais peçonhentos. Rio de Janeiro: EPUB, 1999: 109-34. 
11 JORGE MT., RIBEIRO LA. Epidemiologia e quadro clínico do acidente por cascavel sul-americana (Crotalus durissus). Rev. Inst. Med. Trop., São Paulo, 1992, 34, 347-54.

12 LIRA-DA-SILVA RM. Estudo clínico-epidemiológico dos acidentes ofídicos por Bothrops leucurus WAGLER, 1824 (Serpentes: Viperidae) no Estado da Bahia, Brasil. Salvador: Universidade Federal da Bahia, 1996. 116p. [Dissertação - Mestrado]

13 NASCIMENTO SD. Aspectos epidemiológicos dos acidentes ofídicos ocorridos no Estado de Roraima, Brasil, entre 1992 e 1998. Cad. Saúde Públ., 2000, 16 271-6.

14 RIBEIRO LA. Epidemiology of ophidic accidents. Mem. Inst. Butantan, 1990, 52, 15-6.

15 SALES IC., ALBUQUeRQUE HN., CASTRO LA., BATISTA AR., SILVA ECF, BRAGA SMLFM. Ofidismo no compartimento da Borborema-Paraíba. Rev. Bras. Toxicol., 1999, 12, 88-173. 